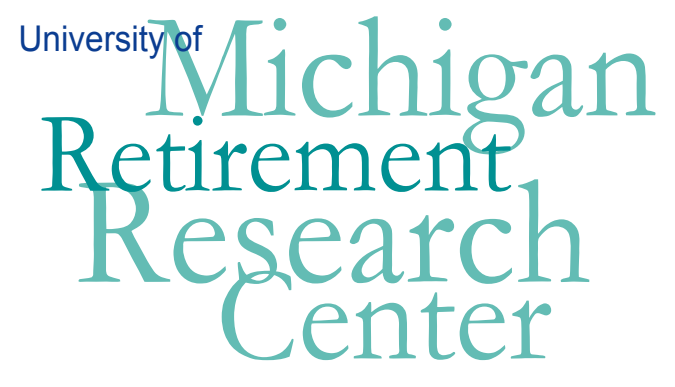

Working Paper

WP 2000-006

\title{
Retirement Responses to Early Social Security Benefit Reductions
}

Olivia S. Mitchell and John W. R. Phillips

\begin{tabular}{|l|l|}
\hline $\mathrm{M}$ & $\mathrm{R}$ \\
\hline $\mathrm{R}$ & $\mathrm{C}$ \\
\hline
\end{tabular}$\quad$ Project \#: UM99-01 


\title{
"Retirement Responses to Early Social Security Benefit Reductions"
}

\author{
Olivia S. Mitchell \\ Wharton School, University of Pennsylvania \\ John W. R. Phillips \\ Social Security Administration
}

September 2000

\author{
Michigan Retirement Research Center \\ University of Michigan \\ P.O. Box 1248 \\ Ann Arbor, MI 48104 \\ www.mrrc.isr.umich.edu \\ (734) 615-0422
}

\section{Acknowledgements}

This work was supported by a grant from the Social Security Administration through the Michigan Retirement Research Center (Grant \# 10-P-98358-5). The opinions and conclusions are solely those of the authors and should not be considered as representing the opinions or policy of the Social Security Administration or any agency of the Federal Government.

\footnotetext{
Regents of the University of Michigan

David A. Brandon, Ann Arbor; Laurence B. Deitch, Bingham Farms; Daniel D. Horning, Grand Haven; Olivia P. Maynard, Goodrich; Rebecca McGowan, Ann Arbor; Andrea Fischer Newman, Ann Arbor; S. Martin Taylor, Gross Pointe Farms; Katherine E. White, Ann Arbor; Mary Sue Coleman, ex officio
} 


\title{
Retirement Responses to Early Social Security Benefit Reductions
}

\author{
Olivia S. Mitchell \\ John W. R. Phillips
}

\begin{abstract}
This paper evaluates potential responses to reductions in early Social Security retirement benefits. Using the Health and Retirement Study (HRS) linked to administrative records, we find that Social Security coverage is quite uneven in the older population: one-quarter of respondents in their late 50's lacks coverage under the Disability Insurance program, and one-fifth lacks coverage for old-age benefits. Among those eligible for benefits, respondents who subsequently retired early appear quite similar initially to those who later filed for normal retirement benefits, but both groups were healthier and better educated than those who later filed for disability benefits. Next we investigate the potential impact of curtailing, and then eliminating, early Social Security benefits. A life-cycle model of retirement behavior provides estimated parameters used to simulate the effects of cutting early Social Security benefits on retirement pathways. We find that cutting early Social Security benefits would boost the probability of normal retirement by twice as much as it would the probability of disability retirement.
\end{abstract}

\section{Authors' Acknowledgements}

This research was conducted with support from the Michigan Retirement Research Center at the University of Michigan, the Population Aging Research Center at the University of Pennsylvania (Mitchell and Phillips), and the Pension Research Council at the Wharton School (Mitchell). Fine research assistance was provided by David McCarthy and Dan Silverman, and very helpful computational assistance by Mike Nolte. Useful comments were provided by Courtney Coile, John Gruber, Howard Iams, and Kalman Rupp. This research is part of the NBER programs on Aging and Labor Economics. Opinions are solely those of the authors and not of the institutions with which the authors are affiliated. Pension Research Council Working Papers are intended to make research findings available to other researchers in preliminary form to encourage discussion and suggestions for revision before final publication. (C2000 Pension Research Council of the Wharton School of the University of Pennsylvania. All Rights Reserved. 


\section{Retirement Responses to Early Social Security Benefit Reductions}

It has been suggested that cutting early Social Security benefits might alleviate the solvency problems facing our national old-age retirement system, since most American workers retire early by filing for Social Security benefits at age 62 (USGA0, 1999: 18). While an early retirement benefit cut could save the system money, it might also impose hardship on some who cannot continue to work. Alternatively, reducing early retirement benefits might induce changes in retirement behavior, inducing some workers to stay on the job to the normal retirement age, while perhaps prompting others to seek Social Security Disability Insurance (DI) benefits. This paper seeks to identify who would be affected by reducing early Social Security benefits, and what potential retirement responses might be anticipated from such a policy change.

Many policymakers appear to believe that retirement patterns would change if early Social Security retirement benefits were reduced. Thus the US General Accounting Office (1999: 2) recently observed that if the early retirement age were raised, "[m]ore older workers would be likely to apply for disability benefits because benefits for retired workers would fall relative to these programs' benefits for the disabled." Similarly, the Social Security Trustees stated that more workers would file for DI in the future, in response to the raising of the normal retirement age under Social Security beyond age 65 (Board of Trustees, 2000). Despite the apparent consensus among policymakers, there is very little evidence on the size and direction of potential worker responsiveness. One study examined age-62 retirees in the HRS and concluded that eliminating early benefits would not impose undue burdens on the older population 
(Burkhauser et al., 1996). ${ }^{1}$ However that analysis excluded those receiving disability benefits so it is not informative about the possibility of people switching from an early to a DI retirement pathway. Below, we provide new evidence on the characteristics of people taking alternative paths into retirement and the likelihood of their responsiveness to this policy change.

In what follows, we first review prior literature and next examine the sociodemographic and economic characteristics of older workers on the verge of retirement. We evaluate how future income and leisure opportunities vary as a function of the retirement pathways open to them, focusing both on eligibility patterns for social insurance programs as well as peoples' levels of other wealth from private sources, namely pensions and financial assets. Next we measure how reducing early Social Security benefits might alter workers' expected retirement wealth and indicate which kinds of older people would be most affected by this change. Then we estimate a behavioral model of how retirement outcomes respond to differences in older workers' wealth, job, demographic characteristics, and health conditions. Finally these estimates are used to simulate how peoples' behavior might change if early Social Security benefits were to be eliminated.

\section{Previous Research}

There are several threads in the economics literature relevant to the topic of older workers and Social Security benefits. One debate, launched by Parsons (1980), attributed most of the post-WWII decline in men's labor-force participation to the Social Security DI program. His conclusion was controversial because several other changes in public and private pensions occurred around the same time, thus confounding the results (Bound, 1979; Haveman and Wolfe

\footnotetext{
${ }^{1}$ Similar findings appear in Uccello (1998), CBO (1999), and USGAO (1999).
} 
1984). Subsequent research queried whether DI enrolment patterns might be due to deteriorating health of older workers. While the research found that health problems do influence older workers' retirement, a time series analysis concluded that older workers are healthier now than in previous decades, and few early retirees are currently in very poor health. ${ }^{2}$ A second literature relevant to this topic has explored econometric issues surrounding applications to the DI program but does not typically control for the influence of employer-provided benefits on retirement choices. ${ }^{3}$ Yet a third strand of labor economics research focuses on how privately-provided pension and retiree health insurance influence retirement choices, but these studies do not generally account for Social Security DI benefits influencing workers' retirement behavior. ${ }^{4}$

In our assessment, prior studies offer only a partial picture of the economic opportunities available to older workers as they contemplate alternative paths into retirement. This is mainly because they tend to cast the labor supply behavior of interest - movement out of the labor force - as a one-period outcome, though in principle the retirement decision should be seen as a life cycle decision. Accordingly, they relate one-period labor supply measures to one-period measures of benefits. As an example, Gruber (1996) analyzed how Canadian men's labor force participation rates changed when one province raised DI benefits by 32 percent. His model relates benefits in a given year to men's labor force participation rates in that same year, and he concludes that the benefit change cut participation by 3 percentage points, from 80 to 77 percent. More generally, one should test whether lifetime benefit streams associated with different pathways into retirement influence retirement outcomes.

\footnotetext{
${ }^{2}$ See Dwyer and Mitchell (1999), Manton et al (1997), Crimmins et al. (1997), Burkhauser, Couch and Phillips (1996), and Smith (1999).

${ }^{3}$ For a review see Bound and Burkhauser (1999); see also Benitez-Silva et al. (2000).

${ }^{4}$ For a recent review of the retirement literature, see Lumsdaine and Mitchell (1999).
} 
A life cycle perspective would therefore pose the decision to seek DI benefits as responsive not to the benefit amount payable in any single year, but rather to the stream of future expected benefits from taking the DI path versus other available retirement options. Thus a more general approach would allow workers' retirement choices to depend on a comparison of expected wealth available from a range of retirement pathways or options (Fields and Mitchell, 1984; Mitchell and Fields, 1987). ${ }^{5}$ One recent study that did adopt a life-cycle perspective in the DI context assessed how West German early retirement incentives interacted with that nation's disability program (Borsch-Supan, 1999). This study used a discrete choice model of retirement among men age 55-70, and it linked retirement choices to a comparison of the wealth value of disability and nondisability pensions. The formulation was similar in spirit to what we do below, with a key difference being that the older workers' budget constraint is collapsed into a single variable. By contrast, here we model separately the value of alternative retirement pathways. Hence, that study overlooks the possibility that a worker might go on to file for normal retirement at some later date, instead of taking either early or disability retirement. Our approach is more general, allowing for people to move across various retirement pathways.

\section{Retirement Incentives in the US Social Security and Disability Insurance System}

In order to evaluate how retirement and disability benefits influence retirement decisions in the U.S., it is essential to understand how workers become insured and what benefits can be received under the US Old-Age, Survivors, and Disability Insurance system (OASDI). As we

\footnotetext{
${ }^{5}$ To illustrate this point in more detail, Gruber's (1996) single-period perspective assumes that retirement responses to the DI change was not influenced by another concurrent change in the benefit structure, namely a lowering of the early retirement age to 60 . A more general model would include not only current DI benefits but also the enhancement of the early retirement option if retirement were delayed. A similar approach is followed by Friedberg (1999) who examines the effect of a precursor program to Social Security, the means-tested U.S. Old Age Assistance program.
} 
shall show, the eligibility and benefit rules are relatively complex, and they interact in complicated ways with workers' earnings and employment histories. ${ }^{6}$

\section{The Rules}

Most older American workers are insured for both old-age and DI benefits, but coverage is by no means uniform across people at different ages. Program rules specify that Social Security retirement benefits are payable only to workers who have contributed long enough to be "fully insured" and who have attained at least age 62, when early retirement is current permitted. $^{7}$ Alternatively, Social Security disability benefits are payable only to those "fully insured for disability purposes"; this requires that the worker must have earned 20 QC's during the last 40 calendar quarters ending in disability. ${ }^{8}$ In other words, any given worker might be both fully nor disability insured, he could be fully but not disability insured, or he could be neither. ${ }^{9}$ As we shall show, variations in eligibility over the lifetime are quite interesting in our data.

Benefit computations use yet a different set of rules. Computing Social Security ER and NR benefits for a fully insured worker requires determining the Average Indexed Monthly

\footnotetext{
${ }^{6}$ For sophisticated descriptions of SSDI program rules see Hu et. al (1997), Hoynes and Moffitt (1997), and Gruber and Kubik (1997), particularly with regard to how SSDI might affect younger recipients' incentives to return to work. In this paper we do not incorporate this possibility since older recipients rarely return to work after becoming DI beneficiaries.

${ }^{7}$ To be fully insured for retirement benefits at age 62 or older, the worker must have 40 QC's (quarters of coverage). QC's are awarded based on having had covered earnings of at least a threshold amount each year. Spouses of fully insured workers are eligible for a spousal benefit regardless of their own work history. Coverage, eligibility, and benefit rules relevant to the HRS cohorts in question appear on the Social Security Administration's web page (www.ssa.gov) or in SSA (1992).

${ }^{8}$ Also to be "disability insured" the worker must (1) have at least 6 QC's and (2) have 1 QC for each year from age 22 to the age of disability (assuming he or she is age 31 or older; special rules apply to younger workers).

${ }^{9}$ A worker could be fully but not DI insured if he had at least ten years of work (so he is fully insured) but lost his disability insurance status due to periods of illness or unemployment.
} 
Earnings (AIME) and his Primary Insurance Amount (PIA). ${ }^{10}$ The monthly benefit amount depends on the worker's retirement age; if he has attained normal retirement age (NR), defined as age 65 for our respondents, his benefit equals his PIA. If retirement occurs before NR, the benefit is reduced by $5 / 9$ of a percent per month below that age. Hence, someone taking benefits at the early entitlement age of 62 (ER) would receive 80 percent of the full PIA for the remainder of his life. The DI benefit equals the eligible worker's PIA; that is, the annual DI and the NR benefits are the same though the DI benefit is payable at a younger age. ${ }^{11}$ Hence retiring at age 62 on DI would provide a Social Security benefit 20 percent larger than the ER benefit. ${ }^{12}$ However applying for DI takes time and effort, and benefits are not always granted. This probabilistic benefit award must therefore be taken into account in assessing one's expected value of retiring on disability. ${ }^{13}$

Retirement Pathways in the HRS

An understanding of the economic opportunities associated with alternative paths to retirement requires us to model individual workers' budget constraints while taking into account actual program rules. To better understand the actual impact of these rules for real workers, we

\footnotetext{
${ }^{10}$ The AIME involves indexing a worker's earnings between 22 and 62 after dropping the 5 lowest years. Indexation links actual covered earnings in a given year to average covered earnings in the same year, and these are then brought forward to the point when the worker is age 60 (earnings after age 60 are entered in nominal rather than indexed form). The PIA formula then applies a 3-tier replacement rate formula to the indexed earnings; the first replacement rate is $90 \%$, the second $32 \%$ and the third, $15 \%$. Cost-of-living adjustments are applied from the PIA calculation year to the retirement year.

${ }^{11}$ Legally, the OASDI system defines disability as "the inability to engage in any substantial gainful activity by reason of medically determinable physical or mental impairment, which can be expected to result in death or which has lasted and can be expected to last for a continuous period of not less than twelve months" (SSA 1992). There is also a five-month waiting period after the onset of disability until the person can apply for benefits.

${ }^{12}$ DI beneficiaries can also receive Medicare 24 months after receiving benefits; accordingly an age-62 DI beneficiary may get Medicare about a year earlier than could an early retiree.

${ }^{13}$ In this study we assume that the probability of receiving DI benefits conditional on application is around 49\%, consistent with the average benefit receipt rate reported over the 1990's (Social Security, 1999).
} 
derived an extract from the nationally representative Health and Retirement Study (HRS), a panel survey of older American households initially interviewed as they were on the verge of retirement (the full sample was age 51-61 in 1992, along with their spouses of any age). This survey is invaluable for our purposes, inasmuch as it contains extensive and detailed information on demographic, health, wealth, income, and employment data for respondents and their spouses. The HRS is especially appropriate for this purpose because respondent records may be linked to administrative data on Social Security earnings and pension plan provisions. ${ }^{14}$ This linkage allows us to compute respondents' eligibility status for benefits as well as the likely benefit amounts that a worker might receive for selecting the early, normal, or disability benefit path.

The period we study spans the eight years between 1992 and $1998 .{ }^{15}$ In order to observe completed retirement transitions for our sample, the analysis examines those persons age 57-61 at baseline in 1992 who have a match to Social Security earnings and benefits data and were not receiving a benefit from Social Security (1,843); by the 1998 wave, this older half of the HRS age-eligible sample attained age 64-67. This enables us to determine, for each respondent, which of three possible retirement paths was taken. These are defined as:

- took disability retirement (DR) prior to age 65;

\footnotetext{
${ }^{14}$ Because of the confidential nature of the administrative data, researchers may access them only under restricted conditions; see www.umich.edu/ hrswww for details. These files were obtained for a majority of HRS respondents, namely those providing permission to link their survey data with administrative records supplied by the Social Security Administration and also with pension plan descriptions provided by respondents' employers. In a few cases Social Security benefits could not be calculated so the respondent had to be omitted from the analysis. One reason for missing Social Security benefits was that respondents gave permission for the University of Michigan to request their Social Security records, but no match was obtained because their records did not match SSA identification information. Also some age-eligible respondents declined to sign the release form permitting their Social Security data to be matched with the HRS (a handful of the very wealthy, some Blacks, and some Hispanics did not provide consent). Omission of nonmatch cases might bias results if those who had a matched file differ from those lacking a match; however exploratory analysis finds little evidence that results are biased.

${ }^{15}$ In this study we use all four waves of the HRS currently available in public or preliminary release status; special permission to link retirement outcomes with restricted data were obtained as required.
} 
- took early retirement (ER) at or between ages 62 and 64; or

- took normal retirement (NR) at or after 65.

Though many sample respondents are eligible for Social Security benefits, some are not for a variety of reasons. Because this analysis focuses on changes in benefit-taking behavior, we accordingly delete from the analysis sample those 299 respondents who were never insured for DI and either ER or NR over the relevant period. ${ }^{16}$

Table 1 summarizes baseline sociodemographic characteristics for the sample in the first column. We also provide summary measures according to the retirement path subsequently chosen (drawn from Waves 2 through 4 of the panel). One interesting fact is that respondents who later became DR recipients were less well educated (52 percent had less than high school versus 24 percent overall), more heavily black (16 percent versus 7 percent overall) and nonmarried (33 percent versus 23 percent), and had more baseline health problems than for the group as a whole (51 percent claim health is fair or poor, versus 13 percent overall). Put differently, those who eventually selected early or normal retirement were both healthier and better educated than those who ended up on DR. Furthermore, those who eventually took early retirement had sociodemographic characteristics quite similar to those who took normal retirement.

\section{Table 1 here}

\section{Retirement Pathways and Retirement Wealth}

Next we examine the budget constraint facing each respondent in the sample. Ex-ante or anticipated wealth values associated with each of the three retirement paths appear in Table $2 .^{17}$

\footnotetext{
${ }^{16}$ The Appendix indicates characteristics of both the full and the subsamples in question.

${ }^{17}$ This analysis postulates that if the individual continued to work until the Social Security early or normal retirement age, he could have continued earning on the same pay trajectory that he was on over
} 
Since the analysis contains only respondents insured for at least two Social Security benefits, it is interesting that, at baseline, 15 percent of the entire sample was not DI-insured. ${ }^{18}$ This fraction varies by eventual retirement path: almost all of those later electing disability retirement were DI-insured at baseline, but 18 percent (12 percent) of the ER (NR) group was not DI insured at baseline.

\section{Table 2 here}

Peoples' lack of insured status results from erratic work histories, and peoples' insured status can change over time, as is shown in Figure 1. Not surprisingly, men in the HRS sample are much more likely to be insured for both OA and DI purposes from the age of about 30, with little change after that; old-age insured rates for men stand at around 95 percent from age $40 \mathrm{on}$. Women are far less likely to be covered for own old-age benefits throughout their careers, with old-age coverage status never exceeding 80 percent. Nevertheless, additional years of work into the 50's and 60's continue to enhance women's insured status at the margin. Turning to insured status for DI, it reaches a maximum during men's prime-age working years but then falls to around 80 percent from age 50 on. By contrast, women's DI coverage status continues to rise over their worklives but never rises above 60 percent, a full 20 percentage points below men's insured status rates.

Figure 1 here

the five years ending in 1991. After projecting this trajectory we ascertain whether the worker would be eligible for benefits at 62 and 65, and then we compute what income streams he could had anticipated according to the relevant ER and NR benefit formulas. Each of these streams is converted to a present value stream using the survival tables and interest rates consistent with the intermediate assumptions of the Social Security Administration. For married respondents, the retirement benefit stream also incorporates the expected present value of spouse and survivor benefits, as relevant. A more detailed explanation of the data creation effort for Social Security benefit amounts appears in Mitchell, Olson and Steinmeier (2000).

${ }^{18}$ For more information regarding patterns in eligibility for Social Security benefits, see Levine et al. (2000). 
More detail on insured status patterns appears in Figure 2, where we relate insured status for OA and DI benefits to early retirement wealth. The results suggest that those in the lowest wealth decile also have the lowest incidence of OASDI insured status: about half of those in the lowest decile are DI-insured, and about two-thirds are OA-insured. Those in the next-highest wealth decile are much more likely to be insured for both OA and DI benefits (about 70 and 86 percent respectively). It is perhaps not surprising that the group least likely to be eligibile for Social Security benefits is also the one with lowest retirement wealth.

Figure 2 here

Three implications follow from these findings. First, older workers are far from universally eligible for Social Security old-age benefits, and those with little retirement wealth are the least likely to be insured. The fact that many older people are ineligible will influence how responsive one might expect the older population to be, to cuts in early Social Security benefits. Second, some who are eligible for old-age retirement benefits will never be eligible for Social Security DI benefits, and hence would not be expected to respond to early benefit cuts by filing for DI. Third, peoples' insured status for both old-age and DI benefits changes over time, so any given change in benefit availability could have little effect in a given year, but it might have a larger effect in some later year when they become eligible.

For each of the three retirement paths considered here, we have computed the present value of wealth anticipated from Social Security as well as total wealth, including financial assets, housing assets and pensions. Table 2 shows that anticipated Social Security wealth is quite similar for those who subsequently choose early and normal retirement, but it is far lower for those who later become DR retirees. For ER and NR the present value of Social Security benefits is on the order of $\$ 162-\$ 174,000$ (for the median 10 percent). But having lower 
eligibility levels and a reduced chance of obtaining DI even if eligible (assumed here to be 49 percent, the population average) reduces expected wealth under the DI alternative to about $\$ 90,000$ over the entire sample. ${ }^{19}$

Table 2 also highlights the powerful role of employee benefits in workers' budget constraints, a factor overlooked in previous DI studies. That is, at baseline almost half of the HRS respondents had employer-provided health insurance coverage; 44 percent had access to disability benefits through their employers; over two-fifths had company-provided retiree health insurance and long-term disability coverage; and 68 percent had a company pension (including those from prior jobs). This is important since prior research shows that defined benefit pension plans impose quite nonlinear benefit accrual paths (Gustman et al., 1999), and provide greater rewards for retiring at one age than some other age. In the case of defined contribution pension plans, benefit accrual patterns are much smoother, changing relatively less as the worker delays retirement. Because company pension accrual paths differ so widely, it is invaluable to have HRS-linked information on the pension algorithms specific to the particular firms employing the surveyed respondents. ${ }^{20}$ Accordingly we characterize covered workers' budget constraints for early, normal, and disability retirement by computing the expected present value of lifetime private pension and disability benefits if the employee worked to age 62 and retired, or if he worked to age 65 and then retired, or if he took the company disability benefit. ${ }^{21}$ Table 2 shows

\footnotetext{
${ }^{19}$ We apply a constant rather than a state-specific probability of eligibility for DI since HRS respondents' state residence codes are not provided in the dataset, unlike Gruber and Kubik (1997) who use state variation in SSDI denial rates. On the other hand, they lack administrative records to determine whether individual respondents are eligible for benefits, and how much actual benefits are at the micro level. Hu et al (1997) have a detailed description of the DI determination process.

${ }^{20}$ For detail on the construction of the pension benefit stream data, see Gustman et al. (2000).

${ }^{21}$ In many corporate pension plans there are special provisions entitling a disabled worker to more generous payments, or benefits payable earlier than otherwise would be the case. To examine this pattern in more detail, we use the pension plan algorithms available from HRS to construct present values of income streams for workers judged to be entitled to disability benefits from their firms. Many employer
} 
that the median 10 percent of pension wealth appears relatively low for the entire sample $(\$ 55,000-57,000)$, but this obscures the fact that many people lacked pension coverage or had low benefits. ${ }^{22}$

Summing all the relevant elements of the budget constraint, we find that the total expected retirement wealth for persons in this sample ranges from $\$ 450,000$ to $\$ 610,000$, depending on the retirement pathway chosen. Specifically, a HRS respondent in the median 10 percent could anticipate a present value of DR wealth of $\$ 451,000$; the ER path by contrast is worth about $\$ 522,000$; and the NR path around $\$ 611,000 .^{23}$ There is much heterogeneity across subgroups in the sample, of course. For instance, DR wealth for those who eventually take DR is about 35 percent less than the full sample value $(\$ 334,000$ versus $\$ 451,000)$. DR retirees also have less housing wealth and fewer other financial assets at baseline. Those who eventually elect early benefits (normal benefits) have about 35 percent (50 percent) more total wealth. We also compute the present value of anticipated earnings if these respondents were to remain employed. Projected earnings are highest for those who end up working the longest. A lesson from Table 2 is the fact that Social Security benefits are only one of several sources of old-age support. That is, retiring early without Social Security ER benefits would be feasible for people having substantial non-Social Security assets such as company-provided pensions and own financial wealth. ${ }^{24}$

disability plans grant company-based disability pensions to any worker deemed eligible for SSDI, so in constructing the budget constraint we assume that the eligibility probability is the same for SSDI as for company disability pensions. SSDI is not means tested, so a worker judged disabled could receive both corporate and government benefits.

${ }^{22}$ Moore and Mitchell (2000) find that pension wealth is on the order of $\$ 150,000-200,000$ for those in the HRS sample with pensions.

${ }^{23}$ Entries in Table 2 are computed for the median $10 \%$ so components will not sum to the totals.

${ }^{24}$ This analysis does not consider the possibility of people applying for Supplemental Security Insurance benefits when early retirement benefits are cut though there might be some program substitution in this 


\section{How Would Cutting Early Social Security Benefits Alter Retirement Wealth?}

If Social Security early retirement benefits were to be cut, a question arises as to how such a policy change might affect the wealth value of alternative paths to retirement. An initial answer to this question appears in Figure 2, where we compare the current distribution of total early retirement wealth with one that might result from ER benefit cuts. This "thought experiment" is one where retirement wealth is recomputed for sample HRS respondents on the assumption that the present value of ER benefits was reduced by $\$ 25,000$ while other sources of wealth remain the same. ${ }^{25}$

It is of interest to note that this experiment has the largest absolute dollar impact on people at the top of the wealth distribution: that is, the wealth value of retiring at 62 would fall by approximately $\$ 25,000$ for someone in the top wealth decile, and it would fall by less for someone in a lower wealth decile, since the benefit is less. But as Figure 3 indicates, the percentage change is largest (20 percent) among the least wealthy and smallest (less than 1 percent) for the wealthiest sample members. This is consistent with previous evidence that Social Security benefits comprise a larger component of retirement wealth among the least wellto-do (Moore and Mitchell 1999), and so a benefit cut would have the largest impact on the less wealthy in percentage terms.

Figure 3 here

A descriptive regression in Table 3 indicates how this wealth change due to a reduction in early Social Security benefits would vary with respondent characteristics. The table reports correlates of the ratio of post- to pre-cut wealth and indicates that those experiencing relatively

direction. We suggest that this is not likely to be a large group inasmuch as many (over half) of those currently eligible for SSI do not seek out the benefits they are currently entitled to.

${ }^{25}$ If benefit present values were too small, benefits were set to zero in the relevant experiments. 
large reductions in ER wealth would be blacks, the less educated, and those in poor health. By contrast, married people would face a smaller wealth reduction, along with those having company-provided pensions. Those fully insured for SSDI purposes would experience a smaller dollar losses from the hypothetical benefit cut. ${ }^{26}$

Table 3 here

\section{Estimation Methodology and Results}

We turn next to the estimation of empirical parameters for a behavioral retirement model, as a function of the economic values of the alternative retirement pathways that people face near retirement.

\section{The Estimation Model}

Our model posits that each retirement path $\mathrm{j}(\mathrm{j}=\mathrm{DR}, \mathrm{ER}, \mathrm{NR})$ has associated with it an expected present value $\left(\mathrm{YRET}_{\mathrm{j}}\right)$, and leisure associated with that choice $\left(\mathrm{L}_{\mathrm{j}}\right){ }^{27}$ For a single individual deciding which of several retirement paths to take, the wealth associated with a given path is the sum of his nonlabor wealth $\left(\mathrm{W}_{\mathrm{a}}\right)$, potential earnings $(\mathrm{E})$ up to age $\mathrm{R}$, and retirement benefits from company pensions and Social Security from age R on (P and SS):

(1) $\quad \operatorname{YRET} T_{j}(R)=W_{i a}+\sum_{a, R} E(t, i j) \cdot s(t) \cdot[1 /(1+r)]^{t}+\sum_{R, D}\left[S S_{t}(R, i j)+P_{t}(R, i j)\right] \cdot s(t) \cdot[1 /(1+r)]^{t}$,

\footnotetext{
${ }^{26}$ As noted above, the dollar gap does not always correlate with percentage changes in wealth. For instance, though blacks and those in poor health would experience smaller dollar changes, they are more likely to have low post- relative to pre-experiment ER wealth (results not provided in detail here).

${ }^{27}$ Modeling the budget constraint so as to include both public and private disability insurance benefits therefore extends the "peak value" concept popularized by Coile and Gruber (1999) in the Social Security context.
} 
where $r$ is a discount factor and $s(t)$ is the probability of surviving an additional year. Benefits are subscripted $i$ for each individual and $j$ by path choice; income values depend on whether the individual contemplates taking the DR, the ER, or the NR path. ${ }^{28}$

Assuming a general utility function with arguments retirement wealth and leisure (retirement years remaining), and a person-specific disturbance term distributed extreme value, the empirical equation for estimation takes the form:

(2) $P\left(Y_{i}=j\right)=\frac{\exp \left[\alpha L_{i j}+\beta Y R E T_{i j}\right]}{\sum_{j=1}^{J} \exp \left[\alpha L_{i j}+\beta Y R E T_{i j}\right]}$.

To predict the probability that choice $\mathrm{j}=1$ would be selected, estimated coefficients may be used to calculate the baseline probabilities for any given model:

(3) $\quad P\left(Y_{i}=1\right)=\frac{\exp \left[\hat{\alpha} L_{i 1}+\hat{\beta} Y R E T_{i 1}\right]}{\sum_{j=1}^{3} \exp \left[\hat{\alpha} L_{i j}+\hat{\beta} Y R E T_{i j}\right]}$

Calculating the change in probability of the first path associated with a "policy" that changes the value of one of the RHS variables, such as a $\$ 25,000$ reduction in the present value of early retirement wealth, requires computing a variable $P O L I C Y$ equal to $Y R E T$ when $j=1$ or 3 and equals $\max (Y R E T-25,000,0)$ if $j=2$. Then we replace YRET in (3) with POLICY and calculate:

(4) $\quad P^{\prime}\left(Y_{i}=1\right)=\frac{\exp \left[\hat{\alpha} L_{i 1}+\hat{\beta} P O L I C Y_{i 1}\right]}{\sum_{j=1}^{3} \exp \left[\hat{\alpha} L_{i j}+\hat{\beta} P O L I C Y_{i j}\right]}$.

The effect of the policy on the probability of accepting path 1 is (4) minus (3):

(5) $d P^{\text {POLICY }}=P^{\prime}\left(Y_{i}=1\right)-P\left(Y_{i}=1\right)$.

\footnotetext{
${ }^{28}$ For married couples the formulation of the budget constraint is somewhat more complex since spouses are entitled to social security and pension benefits, and survivor benefits. The empirical work incorporates these as well.
} 


\section{Estimated Parameters}

Estimated conditional Logit coefficients for the main and three alternative models of the determinants of retirement pathway choice appear in Table 4. Column 1 controls only on pathspecific retirement wealth and leisure, consistent with a utility-based formulation. The second column adds an interaction term between leisure and poor health, in this case measured by selfreported health being "fair" or "poor". ${ }^{29}$ The third column uses an alternative definition of poor health, namely whether the respondent has any impairment limiting his activities in daily living (AnyADL). Finally, the fourth column indicates whether the employee had three job-related benefits: on-the job health insurance, retiree health insurance, and disability insurance.

\section{Table 4 here}

The results for Model (1) confirm, consistent with expectations, that wealth has a positive and statistically significant effect. This implies that that those with more wealth tend to retire earlier, rather than working later. This pattern is repeated in Models (2) and (3), with coefficient estimates being quite stable in magnitude. Model (4) interacts wealth with job benefits, and the statistically significant wealth terms are all positive. Across all four models, the effect of leisure is also positive, but is statistically insignificant. These findings - that wealth and leisure have positive utility weights - are consistent with evidence from prior studies using similar models but relying on older data (Fields and Mitchell, 1984; Mitchell and Fields 1987). The more flexible specification in columns 2-4 suggest that people reporting themselves to be in poor health value leisure differently than those in better health but the estimated effect is statistically insignificant (Model 2). The response is similar when other health measures are used instead.

\footnotetext{
${ }^{29}$ This health measure has been found to be useful in retirement modeling; see Dwyer and Mitchell (1999).
} 
Turning to the controls on job-based benefits, the results prove interesting (Model 4). In principle, one could associate these benefits with additional wealth particular to each retirement pathway and worker. Since the HRS dataset does not indicate a worker's health or disability plan generosity, this option is not available. On the other hand, omitting these plans could bias coefficients on included variables. To check on this possibility, we interact wealth with employer-provided benefits, and it does appear that the wealth effect is more positive for those with job-based health and disability insurance. Having retiree health insurance has no additional impact. $^{30}$

\section{Assessing Estimated Response Parameters}

Because one cannot easily interpret Logit coefficients, estimated response parameters for various changes in explanatory variables are depicted in Table $5 .{ }^{31}$ To obtain these we predict changes in probabilities of selecting each of the retirement paths for each person in the sample and average over relevant categories. The results imply that an across-the-board wealth increase of $\$ 25,000$ would induce more people to select both the DR and ER paths, and fewer people would work on to the normal retirement age. The estimated size of the responses is small however, with the probabilities changing by less than 0.01 . A one-year increase in leisure could also be seen as an upward shift in the budget constraint, and here too the effect would be to retire earlier; again the estimated responses are small. If people were to be in poor instead of good health, they are more likely to be on the DR path, with the likelihood rising by 0.022 or twice as much as moved into ER. Finally, having job-linked benefits such as health and disability insurance tends to encourage longer worklives, reducing the probability of DR by 0.057 to 0.065 ,

\footnotetext{
${ }^{30}$ Likelihood ratio tests indicate that the addition of health and job variables significantly increases the explanatory power of Models 4 relative to Models 1 and 2; see Table 4.
} 
and cutting the ER probability by around 0.02 . The net effect of having more prevalent jobbased benefits is to increase the likelihood of people staying on to normal retirement age, and the magnitudes are larger than other terms. This finding underscores the importance of integrating both government-provided and company-supplied benefits in models of retirement pathways. Table 5 here

\section{Simulating Responses to Cutting Early Retirement Benefits}

To further assess how peoples' retirement patterns might change in response to cuts in early retirement Social Security benefits, we next combine estimated parameters with computed wealth changes to conduct specific simulations.

Impact of Early Retirement Benefit Cuts

Responses to Social Security benefit cuts are derived by simulating how retirement probabilities might change if the present value of only the early retirement Social Security benefit were cut by $\$ 25,000$. An early benefit cut of this magnitude for the median HRS respondent would represent about a 15 percent lower monthly payment over the retiree's remaining lifetime. Since this experiment only alters the early retirement benefit, it represents a kinking of the lifetime budget constraint, leaving unchanged the DR and NR wealth while lowering ER wealth.

The results in Table 6 indicate how our empirical model would predict that workers would respond. Fewer people would elect early retirement, and the response is on the order of a 0.025 reduction of the likelihood of taking ER. Conversely, more people would be predicted to

\footnotetext{
${ }^{31}$ We show results from Model 4 only because the likelihood ratio tests suggest that Model 4 has the most explanatory power. Nevertheless Table 5 results are consistent with those obtained using other models in Table 4.
} 
opt for both NR and DR. The movement to DR is in all cases smaller than the move to NR, with less than half as many moving to disability retirement as compared to normal retirement $(0.006$ versus 0.018 ). In general, however, it is interesting to note that the magnitudes of the simulated response magnitudes are quite small, particularly given the relatively large size of the simulated benefit cut.

\section{Table 6 here}

What if Early Benefits Were Disallowed Altogether?

As an alternative to the benefit reductions described above, one could alternatively ask how retirement patterns might change if Social Security early retirement benefits were eliminated altogether. Of course, people with adequate other income could still exit the labor force at a young age, but under this scenario, they could not receive Social Security early benefits. To simulate how people might respond to such a change, we use the estimated coefficients described above, eliminate the choice of interest (the ER path), and then evaluate equation (5) above for DR and NR. ${ }^{32}$ The results appear in the second row of Table 6 which reports predicted changes in the probability of the DR and the NR paths if ER were to be eliminated. The anticipated flow from early retirement to the disability retirement path $(0.108)$ is

$$
\begin{aligned}
& { }^{32} \text { Specifically we have: } \\
& \text { (6) } P^{\prime}\left(Y_{i}=1 \mid Y_{i}=1 \text { or } 3\right)=\frac{\exp \left[\hat{\alpha} L_{i 1}+\hat{\beta} Y R E T_{i 1}\right]}{\exp \left[\hat{\alpha} L_{i 1}+\hat{\beta} Y R E T_{i 1}\right]+\exp \left[\hat{\alpha} L_{i 3}+\hat{\beta} Y R E T_{i 3}\right]}
\end{aligned}
$$

and

$$
\text { (7) } P^{\prime \prime \prime}\left(Y_{i}=3 \mid Y_{i}=1 \text { or } 3\right)=\frac{\exp \left[\hat{\alpha} L_{i 3}+\hat{\beta} Y R E T_{i 3}\right]}{\exp \left[\hat{\alpha} L_{i 1}+\hat{\beta} Y R E T_{i 1}\right]+\exp \left[\hat{\alpha} L_{i 3}+\hat{\beta} Y R E T_{i 3}\right]} \text {. }
$$

Given this outcome, the effect of eliminating the option on the probability of choosing DR or NR is computed as:

(8) $d P^{\text {NOER }}=P^{\prime}\left(Y_{i}=1\right)-P\left(Y_{i}=1\right)$

(9) $d P^{\text {NOER }}=P^{\prime \prime \prime}\left(Y_{i}=3\right)-P\left(Y_{i}=3\right)$

for DR and NR, respectively. See Allison (1999) for a similar application of this approach. 
less than half the size of the flow to normal retirement $(0.228)$. The simulated patterns are virtually identical across models, consistent with results reported above. ${ }^{33}$

\section{Who Moves Where}

The simulation results agree closely across models yet their effects may differ across people of different characteristics. Table 7 explores this possibility by examining changes in the predicted probabilities of selecting the DR pathway under the simulation experiment, relating it to some of the sociodemographic characteristics of most interest for policy purposes.

\section{Table 7 here}

The estimation shows that several factors are associated with the probability of moving away from an ER retirement pathway toward DR. For instance, people who report themselves to be in poor health are more likely to move to DR, reflecting their higher probability of medical eligibility. Employer benefits also play an important role: those with company-sponsored health and disability insurance have lower probabilities of moving to DR. However, those with retiree health coverage and pensions are more likely to move to DR. Apparently, workers with employer benefits are more likely candidates for DR than those without.

\section{Conclusions}

In this study we ask how reducing early retirement benefits under Social Security might change older workers' life cycle wealth and retirement pathways. The model is a life-cycle one, modeling the choice of retirement options as a function of the expected present value of wealth and leisure associated with each pathway. We use the HRS linked with invaluable administrative records to account for the various income sources available to older workers,

\footnotetext{
${ }^{33}$ The results are virtually identical if we limit analysis to those who are eligible for DR, ER, and NR
} 
including Social Security benefits and employer-sponsored pensions as well as job-based health insurance and disability benefits.

We find that respondents who retire early are quite similar at baseline to those who subsequently elect the NR path, in terms of their health, education, and wealth. Both groups are, however, healthier and better educated than those who later end up on disability retirement. Analysis of the life-cycle budget constraint shows that cutting early Social Security benefits has an uneven effect on the distribution of beneficiaries. Respondents who are black, have low educational attainment, and are in poor health, suffer relatively large losses. Our policy experiment also indicates that early Social Security benefit cuts would have relatively small effects on the probability of early retirement. If early retirement benefits were to be eliminated, more than twice as many HRS respondents would be predicted to work to normal retirement as opposed to taking disability benefits.

In future work we plan to extend the analysis in several directions. We will evaluate the DI application and acceptance process in more detail, and will extend the model allow for additional retirement states. We can also relax the conditional Logit framework to allow more general preference structures though our prior research (Fields and Mitchell 1984) using older datasets found that this did not materially change conclusions. At present, we conclude that Social Security early retirement benefit cuts would induce more workers to delay benefit acceptance as opposed to taking disability benefits.

benefits at the outset of the panel data period. 


\section{References:}

Allison, Paul D. Logistic Regression Using the SAS System: Theory and Application. Cary, NC: SAS Institute Inc., 1999: 175-178.

Benitez-Silva, Hugo, Moshe Buchinsky, Hiu Man Chan, Sofia Cheidvasser, and John Rust. "How Large is the Bias in Self-Reported Disability?" NBER Working Paper No. W7526. February 2000.

Board of Trustees of the Federal Old-Age and Survivors Insurance and Disability Insurance Trust Funds (Board of Trustees), 2000 Annual Report, Social Security Administration, Washington, D.C.: 2000.

Borsch-Supan, Axel. "Incentive Effects of Social Security Under an Uncertain Disability Option”. NBER WP 7339. September 1999.

Bound, John and Richard Burkhauser. "Economic Analysis of Transfer Programs Targeted on People with Disabilities". Handbook of Labor Economics. Eds. Orley Ashenfelter and David Card. New York: Elsevier, 1999: 2417-2528.

Burkhauser, Richard V., Kenneth A. Couch, and John W. Phillips. "Who Takes Early Social Security Benefits: The Economic and Health Characteristics of Early Beneficiaries," The Gerontologist, 36(6). 1996: 789-799.

Coile, Courtney and Jonathan Gruber. "Social Security and Retirement". NBER Summer Institute Working Paper, July 1999.

Crimmins, Eileen, Y. Saito and D. Ingegneri, "Trends in Disability-Free Life Expectancy in the US, 1970-1990: Population and Development Review 23(3) 1997: 555-72.

Dwyer, Debra and Olivia S. Mitchell. "Health Problems as Determinants of Retirement: Are Self-Rated Measures Endogenous?" Journal of Health Economics (18) 1999:173-193.

Fields, Gary S. and Olivia S. Mitchell. Retirement, Pensions, and Social Security. Cambridge, Mass.: MIT Press, 1984.

Friedberg, Leora. "The Effect of Old-Age Assistance on Retirement". Journal of Public Economics. 71. 1999: 213-232.

Gruber, Jonathan. "Disability Insurance Benefits and Labor Supply". NBER WP 5866. December 1996.

Gruber, Jonathan and Jeffrey Kubik. "Disability Insurance Rejection Rates and the Labor Supply of Older Workers". Journal of Public Economics. 64, 1997:1-23.

Gustman, Alan S., Olivia S. Mitchell and Thomas Steinmeier. "The Role of Pensions in the Labor Market." Industrial and Labor Relations Review 47 (3) 1994: 417-438.

Haveman, Robert and Barbara Wolfe. "The Decline of Male Labor Force Participation: Comment." JPE 92(3): 1984: 532-541.

Haveman, Robert and Barbara Wolfe. "Disability Transfers and Early Retirement: A Causal Relationship?" Journal of Public Economics 21, 1984: 47-66. 
Hoynes, Hilary W. and Robert Moffitt. "Tax Rates and Work Incentives in the SSDI Program: Current Law and Alternative Reforms”. NBER WP 6058. June 1997.

$\mathrm{Hu}$, Jianting, Kajal Lahiri, Denton Vaughan, and Bernard Wixon. "A Structural Model of Social Security’s Disability Determination Process”. ORES Working Paper 72, Social Security Administration, August 1997.

Levine, Phillip B., Olivia S. Mitchell, John W. Phillips. “A Benefit of One’s Own: Older Women's Retirement Entitlements Under Social Security". Paper presented at the January 2000 meetings of the American Economic Society, New York.

Lumsdaine, Robin and Olivia S. Mitchell. "New Developments in the Economics of Retirement". In Handbook of Labor Economics. Orley Ashenfelter and David Card, eds. Amsterdam: North Holland, 1999: 3261-3308.

Manton, Ken, L. Corder and E. Stallard. "Chronic Disability Trends in Elderly US Populations: 1982-1994". Proceedings of the National Academy of Sciences 9, March 1997: 2593-98.

Mitchell, Olivia S. and Gary Fields. "Restructuring Social Security: How Will Retirement Ages Respond?" In The Problem Isn't Age: Work and Older Americans. Editor Steve Sandell. New York: Praeger, 1987.

Mitchell, Olivia S, Jan Olson, and Thomas Steinmeier. "Earnings and Projected Benefits". In Forecasting Retirement Needs and Retirement Wealth. Eds. O.S. Mitchell, B. Hammond, and A. Rappaport. Pension Research Council. Philadelphia, PA: University of Pennsylvania Press, 2000: 68-94.

Mitchell, Olivia S. and John Phillips. "Disability, Early, and Normal Retirement”. Paper presented at the Second Annual Joint Conference for the Retirement Research Consortium, The Outlook for Retirement Income, Washington, D.C. May 17-18, 2000.

Parsons, Donald. “The Decline of Male Labor Force Participation.” JPE 88(1): 1980: 117-134.

Smith, Ralph. "Raising the Earliest Eligibility Age for Social Security Benefits". Congressional Budget Office, Washington, D.C. January 1999.

Social Security Administration (SSA). Annual Statistical Supplement to the Social Security Bulletin. US Department of Health and Human Services. Washington, DC: US GPO, 1992.

Uccello, Cori. "Factors Influencing Retirement: Their Implications for Raising Retirement Age”. AARP Public Policy Institute Working Paper \#9810, Washington, DC, October 1998.

U.S. Congressional Budget Office (CBO). Raising the Earliest Eligibility Age for Social Security Benefits. Congressional Budget Office, Washington, DC, January 1999.

U.S. General Accounting Office (GAO). Social Security Reform: Implications of Raising the Retirement Age. GAO/HEHS-99-112.Washington, DC: USGAO, August 1999. 
Table 1: Background Characteristics of HRS Estimation Sample, Overall and by Retirement Pathway ( $\$ 1992)$

\begin{tabular}{|c|c|c|c|c|}
\hline \multirow[b]{2}{*}{ Variable } & \multirow[b]{2}{*}{ Total } & \multicolumn{3}{|c|}{ Retirement Pathway } \\
\hline & & DR & ER & NR \\
\hline \multicolumn{5}{|l|}{ Demographic } \\
\hline Age (years) & 59.4 & 59.0 & 59.5 & 59.3 \\
\hline Female (\%) & 48 & 55 & 50 & 43 \\
\hline Currently Married (\%) & 77 & 67 & 78 & 75 \\
\hline Partner (not married) (\%) & 2 & 3 & 1 & 2 \\
\hline Ever Divorced (\%) & 28 & 38 & 26 & 29 \\
\hline Ever Widowed (\%) & 10 & 18 & 10 & 9 \\
\hline Never Married (\%) & 4 & 4 & 4 & 4 \\
\hline Black $(\%)$ & 7 & 16 & 6 & 7 \\
\hline \multicolumn{5}{|l|}{ Education } \\
\hline LT HS (\%) & 24 & 52 & 25 & 17 \\
\hline High School (\%) & 36 & 31 & 37 & 34 \\
\hline GT HS (\%) & 40 & 17 & 37 & 49 \\
\hline \multicolumn{5}{|l|}{ Health Status } \\
\hline Work Limiting Disability (\%) & 13 & 42 & 14 & 10 \\
\hline Self Report of Health: & & & & \\
\hline Excellent (\%) & 25 & 5 & 24 & 28 \\
\hline Very Good (\%) & 33 & 14 & 34 & 35 \\
\hline Good $(\%)$ & 28 & 30 & 28 & 29 \\
\hline Fair $(\%)$ & 10 & 32 & 11 & 7 \\
\hline Poor $(\%)$ & 3 & 19 & 3 & 1 \\
\hline Difficulty with ADL (\%) & 12 & 28 & 12 & 9 \\
\hline \multicolumn{5}{|l|}{ Doctor-diagnosed Conditions: } \\
\hline Arthritis (\%) & 40 & 58 & 40 & 39 \\
\hline Cancer $(\%)$ & 7 & 7 & 7 & 6 \\
\hline Diabetes $(\%)$ & 10 & 31 & 10 & 9 \\
\hline Heart Problems (\%) & 14 & 29 & 15 & 10 \\
\hline High Blood Pressure (\%) & 41 & 54 & 40 & 42 \\
\hline Lung Disease (\%) & 6 & 12 & 7 & 5 \\
\hline Mental Problems (\%) & 8 & 13 & 8 & 7 \\
\hline Stroke $(\%)$ & 2 & 6 & 2 & 3 \\
\hline CES Depression Score & 21.2 & 25.3 & 21.2 & 20.7 \\
\hline Poor Vision (\%) & 1 & 3 & 1 & 1 \\
\hline Poor Hearing (\%) & 2 & 0 & 3 & 2 \\
\hline $\mathrm{N}$ of Observations & 1,544 & 63 & 951 & 530 \\
\hline$\%$ & 100 & 4 & 62 & 34 \\
\hline
\end{tabular}

Source: Authors' computations using weighted HRS data; see text for sample and Appendix for variable definitions. 
Table 2: Median 10\% of Wealth by Source and Retirement Pathway (\$1992)

\begin{tabular}{|c|c|c|c|c|}
\hline \multirow[b]{2}{*}{ Variable } & \multirow[b]{2}{*}{ Total } & \multicolumn{3}{|c|}{ Retirement Pathway } \\
\hline & & DR & ER & NR \\
\hline \multicolumn{5}{|l|}{ Social Security: } \\
\hline DI Insured, Wave $1(\%)$ & 85 & 97 & 82 & 88 \\
\hline PV SSDR Wealth & $\$ 89,992$ & $\$ 76,786$ & $\$ 89,843$ & $\$ 91,379$ \\
\hline PV SSER Wealth & $\$ 162,133$ & $\$ 117,855$ & $\$ 164,972$ & $\$ 161,709$ \\
\hline PV SSNR Wealth & $\$ 174,353$ & $\$ 128,067$ & $\$ 176,910$ & $\$ 172,999$ \\
\hline \multicolumn{5}{|l|}{ Job-based Wealth:* } \\
\hline Employed, Wave $1(\%)$ & 77 & 72 & 70 & 90 \\
\hline Job Health Ins. (\%) & 50 & 51 & 47 & 53 \\
\hline Job Disability Ins. (\%) & 44 & 44 & 39 & 51 \\
\hline Retiree Health Ins. (\%) & 44 & 40 & 47 & 39 \\
\hline PV Earnings to 62 & $\$ 29,645$ & $\$ 27,708$ & $\$ 23,437$ & $\$ 41,677$ \\
\hline PV Earnings to 65 & $\$ 73,956$ & $\$ 62,791$ & $\$ 58,975$ & $\$ 98,957$ \\
\hline Live Pension (\%) & 40 & 42 & 35 & 50 \\
\hline Pension (\%) & 68 & 66 & 67 & 70 \\
\hline PV DI Pension & $\$ 54,970$ & $\$ 68,702$ & $\$ 48,827$ & $\$ 62,559$ \\
\hline PV ER Pension & $\$ 53,265$ & $\$ 68,173$ & $\$ 48,627$ & $\$ 60,524$ \\
\hline PV NR Pension & $\$ 57,663$ & $\$ 70,054$ & $\$ 50,684$ & $\$ 79,191$ \\
\hline \multicolumn{5}{|l|}{ Other Wealth: } \\
\hline Housing Wealth & $\$ 50,388$ & $\$ 31,540$ & $\$ 54,366$ & $\$ 48,584$ \\
\hline Other Financial Wealth & $\$ 58,865$ & $\$ 14,704$ & $\$ 63,492$ & $\$ 59,579$ \\
\hline Spouse Wealth & $\$ 17,775$ & $\$ 1,894$ & $\$ 16,510$ & $\$ 23,967$ \\
\hline \multicolumn{5}{|l|}{ Total Retirement Wealth: } \\
\hline PV Total DR Wealth & $\$ 451,111$ & $\$ 333,868$ & $\$ 437,945$ & $\$ 483,899$ \\
\hline PV Total ER Wealth & $\$ 522,365$ & $\$ 396,282$ & $\$ 518,592$ & $\$ 543,902$ \\
\hline PV Total NR Wealth & $\$ 611,191$ & $\$ 470,029$ & $\$ 603,664$ & $\$ 644,902$ \\
\hline
\end{tabular}

Notes: See Table 1.

* Job based health, retiree health, and disability insurance statistics from Wave 1 job. 
Table 3: Wealth Impact of Social Security Early Retirement Benefit Reductions

\begin{tabular}{|l|c|}
\hline \multicolumn{1}{|c|}{ Variables } & $\begin{array}{c}\text { OLS Coefficient } \\
\text { (|Standard Error })\end{array}$ \\
\hline Sociodemographic & -0.01 \\
\hline Female & $(0.01)$ \\
Black & $-0.05^{* *}$ \\
Married & $(0.01)$ \\
& $0.08^{* *}$ \\
LT HS & $(0.01)$ \\
& $-0.03^{* *}$ \\
Health Bad & $(0.01)$ \\
& $-0.08^{* *}$ \\
Work-Related & $(0.01)$ \\
\hline Work in 1992 & -0.01 \\
Retire HI & $(0.01)$ \\
Job HI & 0.01 \\
& $(0.01)$ \\
Job DI & 0.00 \\
Pension & $(0.01)$ \\
DI Insured & -0.01 \\
& $(0.01)$ \\
N of Observations & $0.03^{* *}$ \\
R-squared & $(0.01)$ \\
\hline Notes: Sec & $0.03^{* *}$ \\
& $(0.01)$ \\
\hline
\end{tabular}

Notes: See Table 1.

$* * \mathrm{t}>=1.96, * \mathrm{t}>=1.65$.

The dependent variable is the change in the level of retirement wealth after the early retirement benefit cut. Equations include a constant term. 
Table 4: Factors Influencing Choice of Retirement Pathway: Estimated Logit Coefficients $(|\mathrm{SE}|)$

\begin{tabular}{|l|c|c|c|c|}
\hline \multicolumn{1}{|c|}{ Variable } & $\begin{array}{c}\text { Model } \\
\mathbf{( 1 )}\end{array}$ & $\begin{array}{c}\text { Model } \\
\mathbf{( 2 )}\end{array}$ & $\begin{array}{c}\text { Model } \\
\mathbf{( 3 )}\end{array}$ & $\begin{array}{c}\text { Model } \\
\mathbf{( 4 )}\end{array}$ \\
\hline Wealth & $1.69^{* *}$ & $1.75^{* *}$ & $1.75^{* *}$ & $0.59^{*}$ \\
& {$[.21]$} & {$[0.21]$} & {$[0.21]$} & {$[0.25]$} \\
Leisure & 0.12 & 0.04 & 0.09 & 0.16 \\
& {$[0.14]$} & {$[0.14]$} & {$[0.14]$} & {$[0.14]$} \\
Leisure*PoorHealth & & 1.09 & 1.06 & 0.96 \\
& & {$[0.71]$} & {$[0.84]$} & {$[0.67]$} \\
Wealth*Job Health Ins & & & & $1.94^{* *}$ \\
& & & & {$[0.50]$} \\
Wealth*Job Disab Ins & & & & $1.68^{* *}$ \\
& & & & {$[0.54]$} \\
Wealth*Retiree Health Ins & & & & -0.18 \\
& & & & {$[0.56]$} \\
\hline Likelihood Ratio Tests & & & & \\
(chi ${ }^{2}$ ): & & & & \\
$\quad$ vs Model 1 & -- & 3.42 & 1.88 & $49.26^{* *}$ \\
$\quad$ vs Model 2 & -- & -- & -- & $52.69^{* *}$ \\
\hline Outcomes & 4,447 & 4,447 & 4,447 & 4,447 \\
Observations & 1,544 & 1,544 & 1,544 & 1,544 \\
LL & -1582.20 & -1580.49 & -1581.26 & -1555.86 \\
Chi-square & $78.09^{* *}$ & $81.52^{* *}$ & $79.97 * *$ & $130.78^{* *}$ \\
\hline
\end{tabular}

Notes: See Table 1.

$* * \mathrm{t}>=1.96 ; * \mathrm{t}>=1.65$

Poor health: Self-report fair/poor in Eqs (2) and (4) and Any ADL in Eq. (3)

Table 5. Impact of Changes in Explanatory Variables on Retirement Pathways

\begin{tabular}{|l|c|c|c|}
\hline \multicolumn{1}{c|}{$\begin{array}{c}\text { Change in Explanatory } \\
\text { Variable }\end{array}$} & \multicolumn{3}{|c|}{$\Delta$ Predicted Probability from $\Delta$ Explanatory Variable } \\
\cline { 2 - 4 } & $\Delta \mathbf{P}(\mathbf{D R})$ & $\Delta \mathbf{P}(\mathbf{E R})$ & $\Delta \mathbf{P}(\mathbf{N R})$ \\
\hline \$25K Increase in Wealth & 0.003 & 0.002 & -0.005 \\
+1 year Increase in Leisure & 0.000 & -0.004 & 0.004 \\
Poor Health vs Not & 0.022 & 0.011 & -0.033 \\
Job Health Ins. vs None & -0.065 & -0.024 & 0.089 \\
Job Disability Ins. vs None & -0.057 & -0.020 & 0.077 \\
Retiree Health Ins. vs None & 0.006 & 0.002 & -0.008 \\
\hline
\end{tabular}

Notes: See Table 1. Estimates calculated using Model 4 from Table 3. Impact computed by setting categorical variables to 0 versus 1 for all respondents. Impacts for continuous variables estimated at $\$ 25,000$ increase for wealth and 1-year increase for leisure. 
Table 6. Predicted Changes in the Probability of DR and NR given Cuts in Early Retirement Benefits

\begin{tabular}{|l|c|c|c|}
\hline \multicolumn{1}{|c|}{$\begin{array}{c}\text { Policy } \\
\text { Simulation }\end{array}$} & \multicolumn{3}{|c|}{$\Delta$ Predicted Probability from $\Delta$ SSER Policy } \\
\cline { 2 - 4 } & $\Delta \mathbf{P}(\mathbf{D R})$ & $\Delta \mathbf{P}(\mathbf{E R})$ & $\Delta \mathbf{P}(\mathbf{N R})$ \\
\hline Early Retirement Penalty & 0.006 & -0.025 & 0.018 \\
$\begin{array}{l}\text { Elimination of Early Retirement } \\
\text { Benefits }\end{array}$ & 0.108 & -- & 0.228 \\
\hline
\end{tabular}

Notes: See Table 1. Calculations use estimates from Model 4 from Table 3. Impacts for ER benefit reduction computed by reducing estimated SSER wealth by $\$ 25,000$. If respondent has less than $\$ 25,000$ in SSER wealth, then their SSER wealth is set to zero. Impacts for the elimination of SSER calculated by eliminating the ER option and recalculating predicted probabilities (see text for more details).

Table 7. Factors Associated with Changes in Probability of DR If Early Retirement Benefit Cut

\begin{tabular}{|c|c|}
\hline Variable & $\begin{array}{c}\text { OLS Coefficient } \\
(|\mathrm{SE}|)\end{array}$ \\
\hline Female & $\begin{array}{c}0.000 \\
(0.002)\end{array}$ \\
\hline Black & $\begin{array}{l}-0.005 \\
(0.003)\end{array}$ \\
\hline Married & $\begin{array}{l}0.006 * * \\
(0.003)\end{array}$ \\
\hline LT HS & $\begin{array}{l}-0.004 \\
(0.002)\end{array}$ \\
\hline Employed in 1992 & $\begin{array}{c}0.000 \\
(0.002)\end{array}$ \\
\hline Job Health Ins & $\begin{array}{c}-0.044 * * \\
(0.003)\end{array}$ \\
\hline Job Disab Ins & $\begin{array}{c}-0.050 * * \\
(0.002)\end{array}$ \\
\hline Retiree Health Ins & $\begin{array}{l}0.009 * * \\
(0.002)\end{array}$ \\
\hline Poor Health & $\begin{array}{l}0.013^{* *} \\
(0.004)\end{array}$ \\
\hline Any Pension & $\begin{array}{c}0.007 * * \\
(0.002)\end{array}$ \\
\hline $\mathrm{N}$ of observations & 817 \\
\hline R-squared & 0.72 \\
\hline
\end{tabular}

Note: Dependent variable is $\triangle \mathrm{P}(\mathrm{DR})$ given elimination of the ER option; estimates of $\Delta \mathrm{P}(\mathrm{DR})$ from Model 4 , Table 3. Recalculated predicted probabilities derived as in text. 
Figure 1: OASDI Insured Status for HRS Respondents by Age and Sex

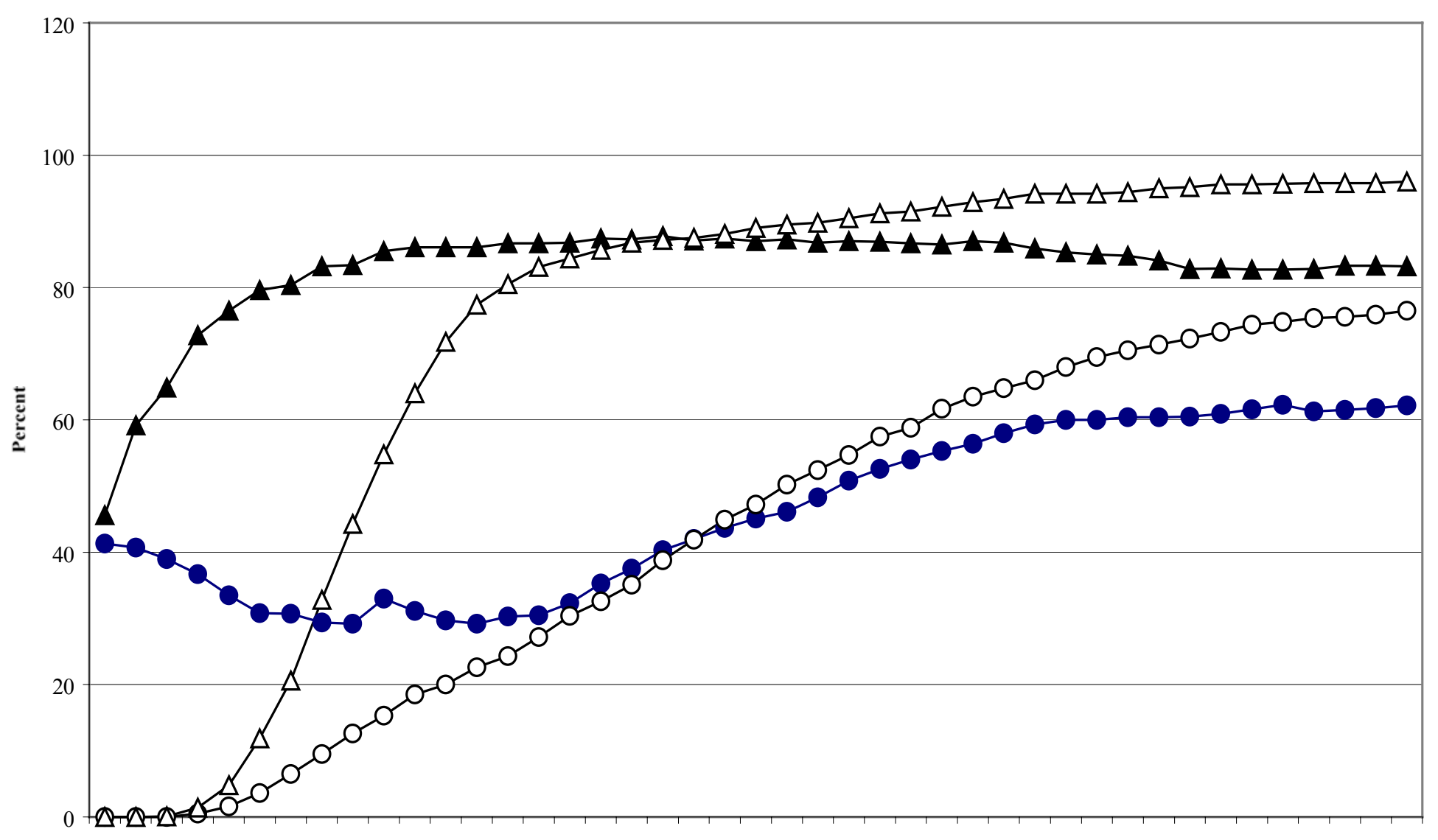

22232425262728293031323334353637383940414243444546474849505152535455565758596061626364

Age

$\rightarrow$ Women (DI) $\quad$ - - Women (OASI) $\quad \longrightarrow$ Men (DI) $\quad \longrightarrow$ Men (OASI)

Source: Authors' computations, weighted HRS; see text and Appendix. 
Figure 2: OASD I Insured Status by Early Retirement Wealth Decile

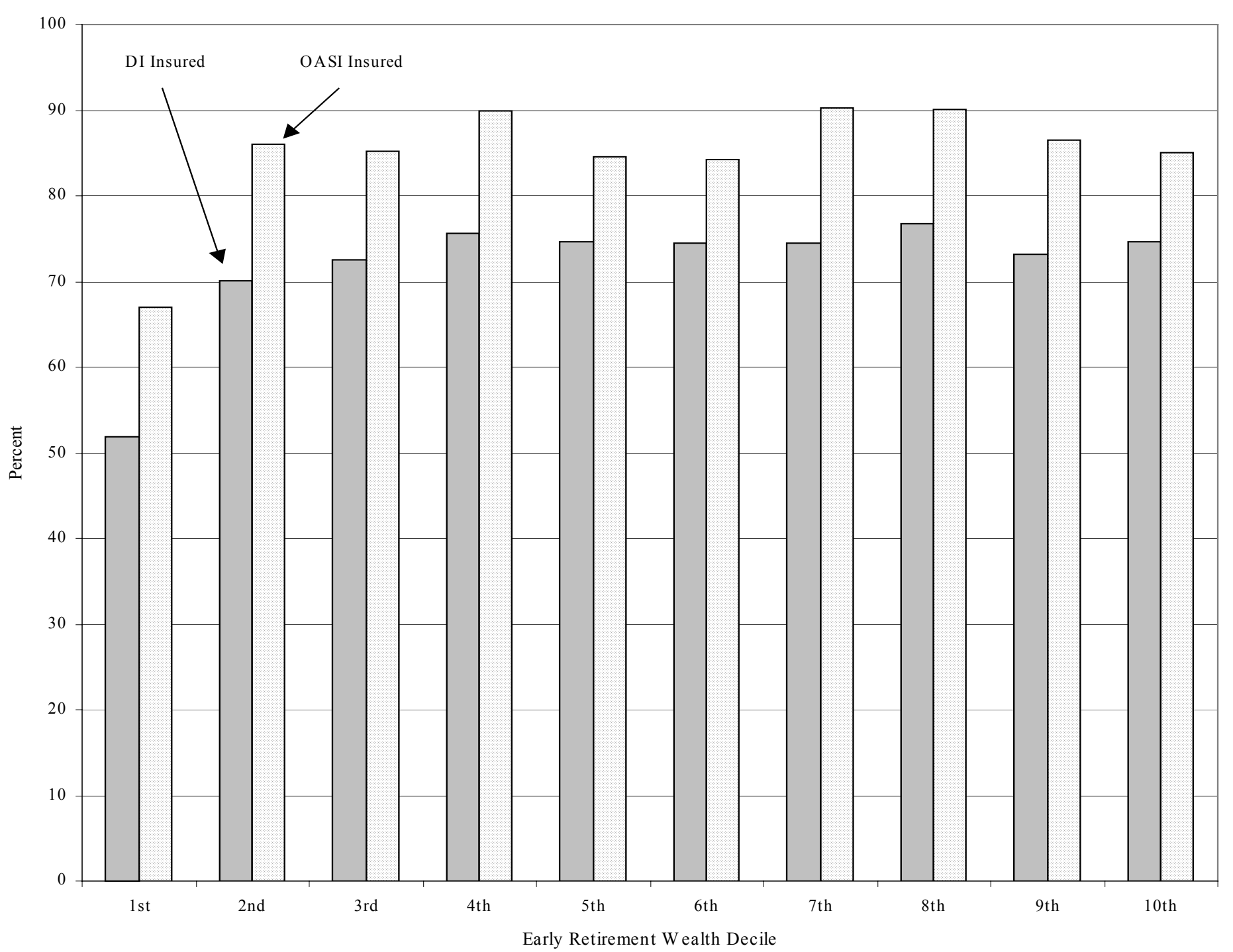

Source: Authors' computations, weighted HRS; see text and Appendix. 
Figure 3: W ealth Impact of Cutting Early Social Security Benefits by $\$ 25,000$

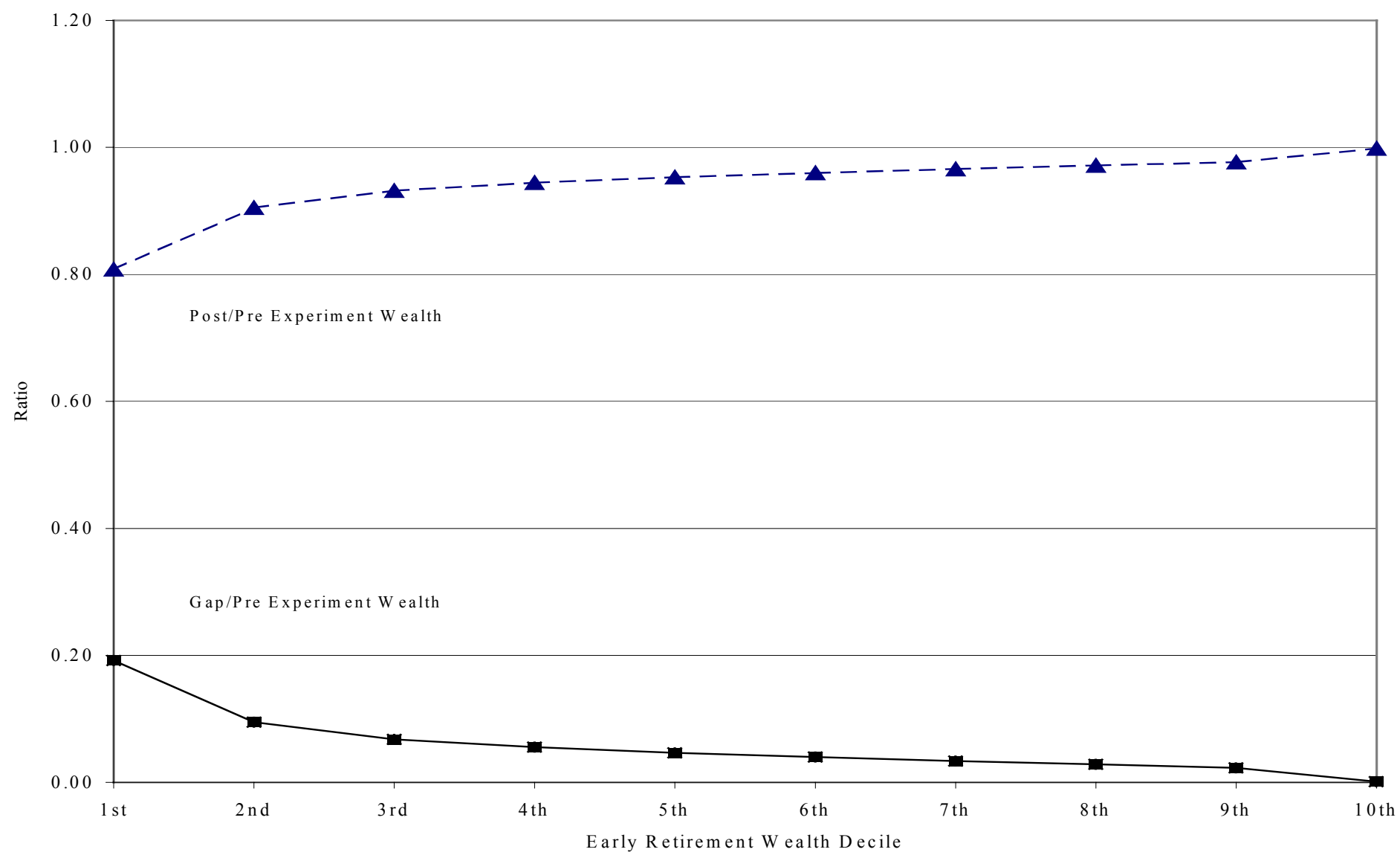

Source: Authors' computations, weighted HRS; see text and Appendix. 


\section{Appendix: Variable Definitions and Sample Means}

Note: All RHS variables measured as of Wave 1

AnyADL: $=1$ if respondent finds it "difficult" to complete any ADL, 0 else.

Age: Respondent's age in years.

Black: $=1$ if respondent black, 0 else.

CES Depression: respondent's CESD score.

Live Pension: $=1$ if has a pension on current job, 0 else.

DI Insured, Wave 1: $=1$ if respondent DI insured based on administrative data, 0 else.

Doctor Diagnosed Condition: $=1$ if respondent reported a condition diagnosed by an MD, 0 else.

Female: $=1$ if respondent female, 0 else.

Housing Wealth: \$ value of home net equity

Job Health Ins: $=1$ if respondent had employer-provided health insurance, 0 else.

Job Disab Ins: $=1$ if respondent had employer-provided long-term disability insurance, 0 else

Leisure ${ }_{\mathrm{ij}}$ : Years of leisure remaining to person i conditional on selecting retirement path $\mathrm{j}$.

LT HS: $=1$ of respondent had less than a high school education, 0 else.

Married: $=1$ if respondent married currently, 0 else.

OA Insured: $=1$ if respondent OA insured based on administrative data, 0 else.

Other Financial Wealth: \$ value of other financial wealth

Pension: $=1$ if has a pension on current or from past job, 0 else.

Poor Vision: $=1$ if respondent reported having poor vision, 0 else.

Poor Hearing: $=1$ if respondent reported having poor hearing, 0 else.

Poor Health: $=1$ if respondent self-reported fair or poor health, 0 else.

PV DR Wealth: \$ value of expected total wealth if respondent elected DR.

PV ER Wealth: \$ value of expected total wealth if respondent elected ER.

PV NR Wealth: \$ value of expected total wealth if respondent elected NR.

PV Earnings to 62: PV of expected earnings if work to 62

PV Earnings to 65: PV of expected earnings if work to 65

PV DR Pension: \$ value of wealth from employer-provided disability pension

PV ER Pension: \$ value of wealth from employer-provided early retirement pension

PV NR Pension: \$ value of wealth from employer-provided normal retirement pension

PV SSDR: \$ value of expected Social Security wealth if respondent elected DR.

PV SSER: \$ value of expected Social Security wealth if respondent elected ER.

PV SSNR: \$ value of expected Social Security wealth if respondent elected NR.

Retiree Health Ins: $=1$ if respondent had employer-provided retiree health insurance, 0 else

Spouse Wealth: \$ expected value of spouse pension (if any)

Wealth $_{\mathrm{ij}}$ : PV of expected wealth available to person i conditional on selecting retirement path $\mathrm{j}$.

Work in 1992: $=1$ if respondent has a job in 1992, 0 else.

Work Limiting Disability: $=1$ if respondent reported some work limiting disability, 0 else. 
Appendix Table: Background Characteristics of Full EBS/HRS Estimation Sample, Overall and by Retirement Pathway (\$1992)

\begin{tabular}{|c|c|c|c|c|}
\hline \multirow[b]{2}{*}{ Variable } & \multirow[b]{2}{*}{ Total } & \multicolumn{3}{|c|}{ Retirement Pathway } \\
\hline & & DR & ER & NR \\
\hline \multicolumn{5}{|l|}{ Demographic } \\
\hline Age (years) & 59.4 & 59.0 & 59.5 & 59.2 \\
\hline Female (\%) & 53 & 58 & 56 & 49 \\
\hline Currently Married (\%) & 77 & 60 & 79 & 76 \\
\hline Partner (not married) (\%) & 1 & 2 & 1 & 2 \\
\hline Ever Divorced (\%) & 26 & 42 & 25 & 27 \\
\hline Ever Widowed (\%) & 10 & 18 & 10 & 9 \\
\hline Never Married (\%) & 4 & 5 & 4 & 4 \\
\hline Black (\%) & 7 & 15 & 6 & 7 \\
\hline \multicolumn{5}{|l|}{ Education } \\
\hline LT HS (\%) & 24 & 53 & 26 & 18 \\
\hline High School (\%) & 37 & 34 & 39 & 33 \\
\hline GT HS (\%) & 39 & 13 & 35 & 49 \\
\hline \multicolumn{5}{|l|}{ Health Status } \\
\hline Work Limiting Disability (\%) & 16 & 51 & 15 & 12 \\
\hline Self Report of Health: & & & & \\
\hline Excellent (\%) & 24 & 3 & 23 & 27 \\
\hline Very Good (\%) & 32 & 15 & 34 & 34 \\
\hline Good (\%) & 28 & 27 & 28 & 28 \\
\hline Fair $(\%)$ & 12 & 30 & 12 & 9 \\
\hline Poor $(\%)$ & 4 & 25 & 4 & 2 \\
\hline Difficulty with ADL (\%) & 14 & 36 & 13 & 11 \\
\hline \multicolumn{5}{|l|}{ Doctor-diagnosed Conditions: } \\
\hline Arthritis (\%) & 42 & 64 & 42 & 41 \\
\hline Cancer $(\%)$ & 6 & 6 & 7 & 6 \\
\hline Diabetes (\%) & 11 & 28 & 10 & 10 \\
\hline Heart Problems (\%) & 14 & 26 & 15 & 11 \\
\hline High Blood Pressure (\%) & 41 & 54 & 40 & 42 \\
\hline Lung Disease (\%) & 7 & 16 & 7 & 6 \\
\hline Mental Problems (\%) & 9 & 13 & 9 & 9 \\
\hline Stroke $(\%)$ & 2 & 6 & 2 & 3 \\
\hline CES Depression Score & 21.5 & 25.8 & 21.4 & 21 \\
\hline Poor Vision (\%) & 2 & 9 & 2 & 1 \\
\hline Poor Hearing $(\%)$ & 2 & 0 & 3 & 2 \\
\hline \multicolumn{5}{|c|}{ Total PDV of Wealth by Benefit Type } \\
\hline DI Insured, Wave $1(\%)$ & 74 & 66 & 72 & 71 \\
\hline OA Insured, Wave $1(\%)$ & 83 & 87 & 87 & 79 \\
\hline PV Total DR Wealth & $\$ 423,525$ & $\$ 201,745$ & $\$ 409,022$ & $\$ 477,340$ \\
\hline PV Total ER Wealth & $\$ 507,660$ & $\$ 262,987$ & $\$ 504,758$ & $\$ 541,819$ \\
\hline PV Total NR Wealth & $\$ 586,040$ & $\$ 315,080$ & $\$ 582,628$ & $\$ 626,536$ \\
\hline $\mathrm{N}$ of Observations & 1,843 & 92 & 1,092 & 659 \\
\hline$\%$ & 100 & 5 & 59 & 36 \\
\hline
\end{tabular}

Source: Authors' computations, weighted HRS; see text. 